\title{
小児における粘液囊胞の臨床統計的観察
}

$$
\begin{aligned}
& \text { 津 留 昭二・杉本忠雄 -中村貴 司 } \\
& \text { 岡田正明・陸方・前川俊之 } \\
& \text { 三浦 正 明 - 真 辺健一・詫磨 智 恵 } \\
& \text { 黒川英 雄・梶山稔 }
\end{aligned}
$$

平成 4 年 2 月 26 日受理

\section{Clinical and Statistical Observation on the Mucous Cysts in Children at Our Clinic}

Shoji Tsuru, Tadao Sugimoto, Takashi Nakamura, Masaaki Okada, Lu-Fang, Toshiyuki Maekawa, Masaaki Miura, Kenichi Manabe,

Chie Takuma, Hideo Kurokawa and Minoru Kajiyama

Second Department of Oral Surgery (Chief : Prof. Minoru Kajiyama)

Kyushu Dental College, Kitakyushu, Japan

Eighty-four pediatric patients, out of the 195 patients diagnosed as mucous cyst and who visited our clinic between 1987 and 1990, were clinically and histopathologically analysed.

1) Pediatric patients diagnosed as mucous cyst numbered 84 children, which is $43.1 \%$ of all of the 195 patients.

2) Male/female ratio was $1: 1.4$ in all of our patients, whereas $1: 1.9$ in children, and $1: 2.6$ in patients under 10 years of age. Female patients were more than male in children.

3 ) The lesion in the majority of pediatric patients was located on the lower lip but occurred with lesser frequency on the tongue, the floor of the mouth, and other regions.

4) All cases were found histopathologically to be of the three types (Matsuoka's classification); the type I was $28.7 \%$, the type II $69.7 \%$, and the type III $1.5 \%$. As to pediatric patients, type I was $38.1 \%$, the type II $60.7 \%$, and the type III $1.2 \%$.

5 ) Treatment was mostly surgical removal in children as well as in adults.

6) The recurrence of the lesion was found in only 3 cases (3.5\%) in children.

Key words : Mucous cyst/Oral cavity/Child

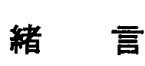

粘液車胞は大·小睡液腺からの唾液流出障害によって 発生する蓑胞で'，日常の臨床でしばしば経験する疾患 である。しかしながら，小児例㧍よび成人例との臨床的 な比較調查報告は少ない22. 今回, 著者らはこれまでに
当科で経験した粘液毫胞 195 例のうち小児（15 歳未満） 84 例について，臨床的所見ならびに病理組織学的所見 を, 成人例のそれ之比較検討を行い, 若干の知見を得た ので，その成績を報告する.

\section{調查対象例}


調查対象例は 1978 年から 1990 年までの過去 13 年間 に，九州歯科大学第 2 口腔外科を受診し，処置を受けた 粘液桽胞のうち, 組織学的に確定診断しえた 195 例・ 200 襄胞である，な抢，口底に発現したガマ腫，舌下面 に発現したブランダン腺囊胞については，いずれ屯粘液 囊胞として取り扱い, これに含めた。

\section{調查成績}

\section{1. 年齢別発現頻度について}

調査しえた粘液囊胞 195 例では， 1 歳から 75 歳まで の幅広い年齢層に発現していたが, 10 歳未満では 47 例 (24.1\%)，10 歳台のうち 15 歳未満が 37 例 (19.0\%) となり，小児口腔外科学会対象患者年榆（15 歳未満） での発現例が 84 例 $(43.1 \%)$ となり，全例の半数近く

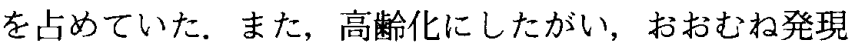

表 1 当科における粘液豪胞発現例の年齢と性別に ついて (1978 1990； 195例）

\begin{tabular}{|c|c|c|c|}
\hline 年齢 & 男（\%） & 女 (\%) & 計（\%） \\
\hline $0 \sim 9$ & $13(27.7)$ & $34(72.3)$ & $47(24.1)$ \\
\hline $10 \sim 14$ & $16(43.2)$ & $21(57.8)$ & $37(19.0)$ \\
\hline $15 \sim 19$ & $9(45.0)$ & $11(55.0)$ & $20(10.3)$ \\
\hline $20 \sim 29$ & $9(42.9)$ & $12(57.1)$ & $21(10.8)$ \\
\hline $30 \sim 39$ & $14(43.8)$ & $18(56.2)$ & $32(16.4)$ \\
\hline $40 \sim 49$ & $7(41.2)$ & $10(58.8)$ & $17(8.7)$ \\
\hline $50 \sim 59$ & $9(69.2)$ & $4(30.8)$ & $13(6.7)$ \\
\hline $60 \sim 69$ & $4(66.7)$ & $2(33.3)$ & $6(3.1)$ \\
\hline 70以上 & $0(0.0)$ & $2(100.0)$ & $2(1.0)$ \\
\hline $\begin{array}{l}\text { 計 } \\
(\%)\end{array}$ & $\begin{array}{c}81 \\
(41.5)\end{array}$ & $\begin{array}{c}114 \\
(58.5)\end{array}$ & $\begin{array}{c}195 \\
(100.0)\end{array}$ \\
\hline
\end{tabular}

頻度は低くなっていたが，とくに30 歳台に多発してい ることが注目された（表 1 ）。

2. 性別発現頻度について

195 例に招ける性別発現頻度をみると，男が 81 例 (41.5\%)，女は 114 例（58.5\%）で，男女比は 1：1.4 となり著差は認められなかった。しかしながら 10 歳台 以下では男女比が $1: 2.6$ 之約 2 倍強となり，低年齢層 ほど女児に多発していた（表1，図1）。

3 ．部位別発現頻度について

195 例を発現部位別に調査したところ，下唇が最屯多 く 111 例（56.9\%）と過半数を占め，ついで口底が 51 例 (26.2\%), 舌下面が 23 例（11.8\%）となり，ついで,

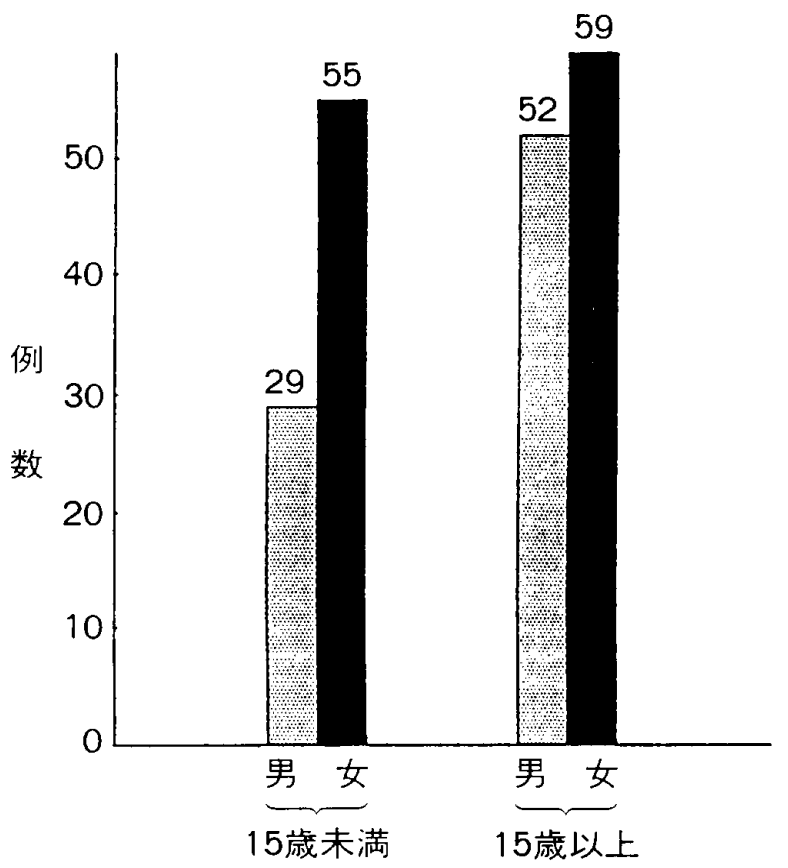

図 1 当科における粘液囊胞発現例の年齢之性別に ついて （1978 1990，195 例）

表 2 当科における粘液䧶胞発現例の発現部位について

(1978 1990，195例)

\begin{tabular}{c|c|c|r}
\hline \hline 発現部位 & 15歳未満 & 15歳以上 & \multicolumn{1}{|c}{ 計 $(\%)$} \\
\hline 下 唇 & $52(61.9)[2]$ & $59(53.2)[1]$ & $111(56.9)$ \\
口 底 & $15(17.9)$ & $36(32.4)[1]$ & $51(26.2)$ \\
舌下面 & $16(19.0)$ & $7(6.3)$ & $23(11.8)$ \\
煩粘膜 & $0(0.0)$ & $8(7.2)$ & $8(4.1)$ \\
歯肉・歯槽粘膜 & $1(1.2)$ & $1(0.9)$ & $2(1.0)$ \\
\hline 計 & 84 & 111 & 195 \\
$(\%)$ & $(43.1)$ & $(56.9)$ & $(100.0)$ \\
\hline
\end{tabular}

内は多発例を示す。 
煩粘膜，歯肉·歯槽粘膜がそれにつづいていた。なお， 上唇での発現例はみられず，興味ある調査結果であった (表 2 ).

15 歳未満の小㫛では, 84 例のうち, 下唇が 52 例 (61.9\%) と半数例以上を占め, ついで舌下面が 16 例 $(19.0 \%) ，$ 口底が 15 例 (17.9\%)，歯肉·歯槽粘膜が 1 例 $(1.2 \%)$ で, 多くの症例が下唇に発現し, 制粘膜で の発現例はみられなかった。一方，15歳以上の症例で は下唇が 59 例と，小児之同様に半数以上を占め，つい で口底が 36 例, 煩粘膜が 8 例, 舌下面が 7 例, 歯肉. 歯槽粘膜が 1 例であった。 また, 多発例は 15 歳未満お よび 15 歳以上の症例にそれぞれ 2 例が認められた。

以上の調査結果からすれば，下唇はいずれの年齢層で 6多発していたが，15歳以上の症例では，口底に多発 し, 舌下面, 頖粘膜がこれにつついていた。しかしなが

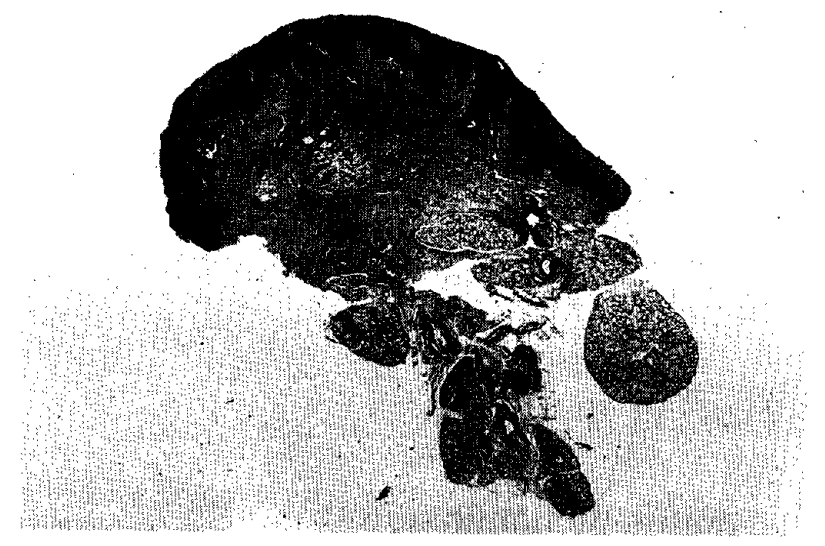

写真 1 粘液肉芽腫型（I 型）症例の病理組織所見 (H.E. 染色，弱拡大)

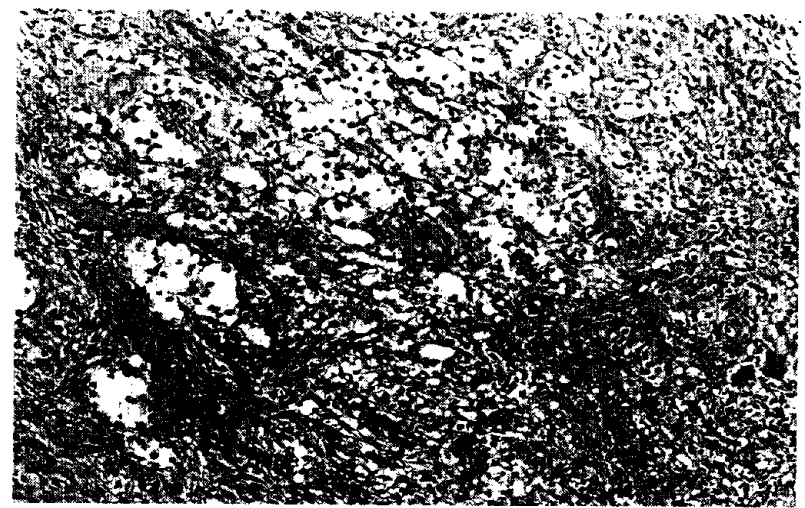

写真 2 粘液肉芽腫型（I 型）症例の病理組織所見 (H. E. 染色, 強拡大)

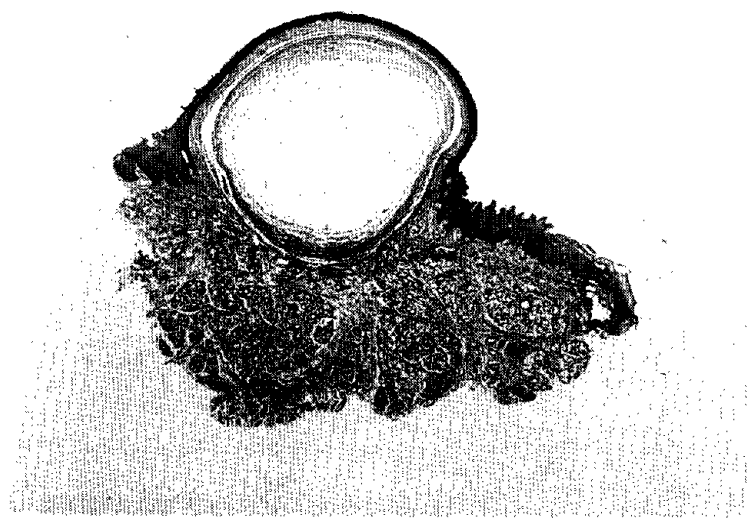

写真 3 囊腫型（II 型）症例の病理組織所見 (H. E. 染色，弱桩大）

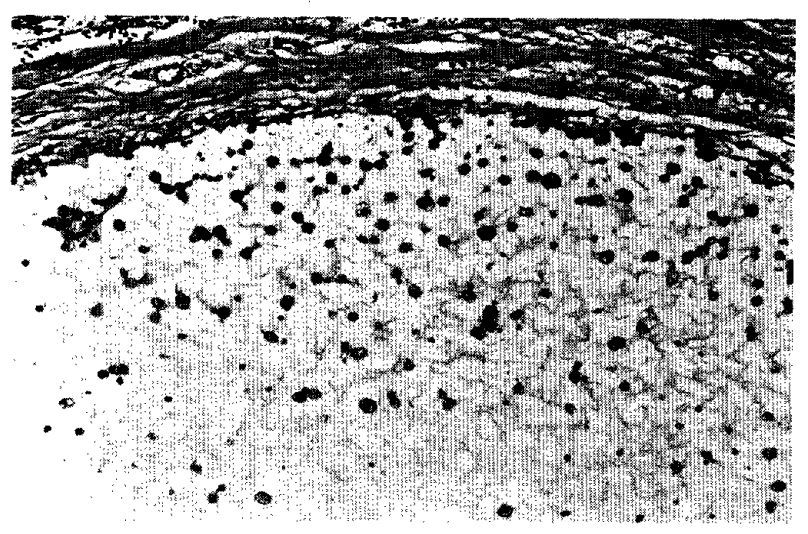

写真 4 襄腫型 (II 型) 症例の病理組織所見 （H.E. 染色，強拡大）

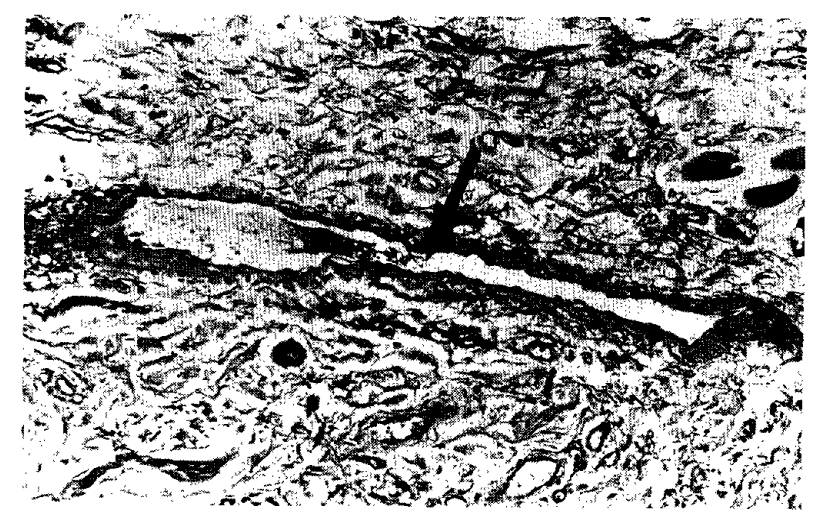

写真 5 排泄管拡張型 (III型) の病理組織所見 (H. E. 染色) 
ら小児では口底例が比較的少なく，乱下面で多発すると いう傾向が認められた。

なお，同一症例における多発例については，小児で下 唇に 2 例，15 歳以上では下唇および口底にそれぞれ 1 例認められたが, 調查例全般からすれば $2.1 \%$ と比較的 低い発現頻度でまれな症例といえる。

4. 病理組織学的所見について

粘液亳胞の組織学的分類については, 1972 年, 松岡 ら ${ }^{32}$ が以下のように分類している，すなわち，

I 型：粘液肉芽腫の型を呈するもの（写真 1,2 ）.

П型：肉芽組織ないしは線維性結合組織により，車胞 が形成されているあの（写真 3，4）.

III型：肉芽腫性の変化がみられず，著明に拡張した排 泄管を主病変とするすの（写真 5 ).

表 3 当科における粘液荃胞発現例の組織分類につ いて (1978 1990，195例）

\begin{tabular}{c|c|c|c}
\hline \hline 組織分類 & 15歳未満 & 15歳以上 & 計 (\%) \\
\hline I 型 & $32(38.1)$ & $24(21.6)$ & $56(28.7)$ \\
II 型 & $51(60.7)$ & $85(76.6)$ & $136(69.8)$ \\
III型 & $1(1.2)$ & $2(1.8)$ & $3(1.5)$ \\
\hline 計 & 84 & 111 & 195 \\
$(\%)$ & $(43.1)$ & $(56.9)$ & $(100.0)$ \\
\hline
\end{tabular}

I 型 : 粘液肉芽腫の型を呈するもの

II 型：肉芽組織ないしは線維性結合組織により, 胞が形成されているあの

III型 : 肉芽腫性の変化がみられず, 著明に拡張した 排泄管を主病変とするもの
などの 3 型である.

自験 195 例を松岡分類 $(1972)^{33}$ に準じて調査したと

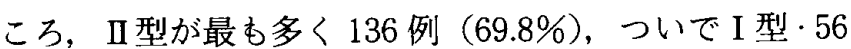
例 $(28.7 \%)$, III型· 3例 $(1.5 \%)$ であった。

な抢，15 歳以上の症例については，I 型·24 例 (21.6\%)， II 型· 85 例 $(76.6 \%) ，$ III型・ 2 例 $(1.8 \%)$ で，II型が I 型の約 3 倍強となっていた。これに対し 15 歳未満の小児では， I 型· 32 例 $(38.1 \%) ，$ II 型· 51 例 $(60.7 \%) ，$ III型・1 例 $(1.2 \%)$ となり，15 歳未満お よび 15 歳以上の症例において，いずれも I 型と II 型の 症例数が多かった。また，15 歳末満の小児例では $\mathrm{I}$ 型 の頻度が高く, 15 歳以上例では I 型の発現頻度がいく ぶん低くなっていたが，全般的には差違は認められな かった（表 3 ).

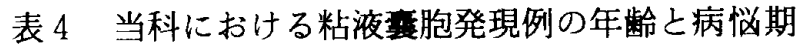
間について (1978 1990，195例)

\begin{tabular}{|c|c|c|c|}
\hline 病悩期間 & 15歳未満 & 15歳以上 & 計（計） \\
\hline 1 週間以内 & $7(8.3)$ & $6(5.4)$ & $13(6.7)$ \\
\hline 2 週間以内 & $12(14.3)$ & $10(9.0)$ & $22(11.3)$ \\
\hline 1 出月以内 & $22(26.2)$ & $33(29.7)$ & $55(28.2)$ \\
\hline 3 加月以内 & $21(25.0)$ & $34(30.6)$ & $55(28.2)$ \\
\hline 6 か月以内 & $13(15.5)$ & $15(13.5)$ & $28(14.4)$ \\
\hline 1 年以内 & $5(5.9)$ & $6(5.4)$ & $11(5.6)$ \\
\hline 5 年以内 & $4(4.8)$ & $5(4.5)$ & $9(4.6)$ \\
\hline 10 年以内 & $0(0.0)$ & $2(1.8)$ & $2(1.0)$ \\
\hline $\begin{array}{l}\text { 計 } \\
\text { (\%) }\end{array}$ & $\begin{array}{c}84 \\
(43.1)\end{array}$ & $\begin{array}{c}111 \\
(56.9)\end{array}$ & $\begin{array}{c}195 \\
(100)\end{array}$ \\
\hline
\end{tabular}

表 5 当科における粘液喜胞発現例の病悩期間と組織分類につ いて (1978 1990， 195例)

\begin{tabular}{|c|c|c|c|c|}
\hline $\begin{array}{l}\text { 病悩期間 } \\
\text { 組織分類 }\end{array}$ & I 型 & II 型 & III 型 & 計（\%） \\
\hline 1 週間以内 & $4(7.1)$ & $8(5.9)$ & $1(33.3)$ & $13(6.7)$ \\
\hline 2 週間以内 & $5(8.9)$ & $17(12.5)$ & & $22(11.3)$ \\
\hline 1 吕月以内 & $17(30.4)$ & $37(27.2)$ & $1(33.3)$ & $55(28.2)$ \\
\hline 3 加月以内 & $12(21.4)$ & $42(30.9)$ & $1(33.3)$ & $55(28.2)$ \\
\hline 6 加月以内 & $11(19.6)$ & $17(12.5)$ & & $28(14.4)$ \\
\hline 1 年以内 & $3(5.4)$ & $8(5.9)$ & & $11(5.6)$ \\
\hline 5 年以内 & $2(3.6)$ & $7(5.1)$ & & $9(4.6)$ \\
\hline 10 年以内 & $2(3.6)$ & & & $2(1.0)$ \\
\hline $\begin{array}{c}\text { 計 } \\
(\%)\end{array}$ & $\begin{array}{c}56 \\
(28.7)\end{array}$ & $\begin{array}{c}136 \\
(69.7)\end{array}$ & $\begin{array}{c}3 \\
(1.5)\end{array}$ & $\begin{array}{c}195 \\
(100)\end{array}$ \\
\hline
\end{tabular}


5. 病悩期間について

自験 195 症例の病悩期間についてみると, 早期の症例 では 1 日から, 長いものでは 10 年までと, 様々であっ たが，15歳末満の小児例，および 15 歳以上例ともに, 2 週間以上から 3 か月以内の症例で半数以上を占めてい たが，両者のあいだにとくに差違は認められなかった (表 4 ).

また，病悩期間と組織分類についても，特別な関係は 認められなかった（表 5).

6. 治療法と予後について

同一症例における多発 4 例を含めた 195 例 $\cdot 200$ 襄胞 について，その治療法と予後について調查した。

まず，治療法については，切除摘出術が 200 表胞中 190 囊胞 (95.0\%) と大多数を占め, 開空術（比較的大 きな，いわゆるガマ腫）はわずか 10 例 (5.0\%) であっ た.

15 歳未満の小児についてみると, 84 症例 86 襄胞のう ち大多数の 84 襄胞に切除摘出術が行われており, 開空 術はわずか 2 例であった。

次に予後についてみると, 200 襄胞中, 再発は 9 例

表 6 当科における粘液襄胞の治療法之再発例につ いて（1978～1990，195例，200错胞）

\begin{tabular}{c|c|c|c}
\hline \hline 治療 法 & 15 歳未満 & 15 歳以上 & 計 $(\%)$ \\
\hline 開 㥶 & $\begin{array}{c}2 \\
{[0 \cdot(0.0)]}\end{array}$ & $\begin{array}{c}8 \\
{[2 \cdot(25.0)]}\end{array}$ & $\begin{array}{c}10(5.0) \\
{[2 \cdot(20.0)]}\end{array}$ \\
\hline 摘出切除 & $\begin{array}{c}84 \\
{[3 \cdot(3.6)]}\end{array}$ & $\begin{array}{c}106 \\
{[4 \cdot(3.8)]}\end{array}$ & $\begin{array}{c}190(95.0) \\
{[7 \cdot(3.7)}\end{array}$ \\
\hline 計 & $\begin{array}{c}86 \\
{[3 \cdot(3.5)]}\end{array}$ & $\begin{array}{c}114 \\
{[6 \cdot(5.3)]}\end{array}$ & $\begin{array}{c}200(100) \\
{[9 \cdot(4.5)]}\end{array}$ \\
\hline
\end{tabular}

[ ] 内は再発した衰胞数・再発率 $(\%)$ を示す.

表 7 性別による再発率について

（1978～1990，195例，200裏胞）

\begin{tabular}{c|c|c|c}
\hline \hline 性 別 & 15 歳未満 & 15 歳以上 & 計 $(\%)$ \\
\hline 男 & $\begin{array}{c}30 \\
{[0 \cdot(0.0)]}\end{array}$ & $\begin{array}{c}52 \\
{[2 \cdot(3.8)]}\end{array}$ & $\begin{array}{c}82 \\
{[2 \cdot(2.4)]}\end{array}$ \\
\hline 女 & $\begin{array}{c}56 \\
{[3 \cdot(5.4)]}\end{array}$ & $\begin{array}{c}62 \\
{[4 \cdot(6.5)]}\end{array}$ & $\begin{array}{c}118 \\
{[7 \cdot(5.9)]}\end{array}$ \\
\hline 計 & $\begin{array}{c}86 \\
{[3 \cdot(3.5)]}\end{array}$ & $\begin{array}{c}114 \\
{[6 \cdot(5.3)]}\end{array}$ & $\begin{array}{c}200 \\
{[9 \cdot(4.5)]}\end{array}$ \\
\hline
\end{tabular}

[ ] 内は再発した㱳胞数・再発率（\%) を示す.
で，再発率は $4.5 \%$ であった，そのうち 15 歳未満の小 児では， 86 襄胞中 3 襄胞 $(3.5 \%)$ に再発がみられ，15

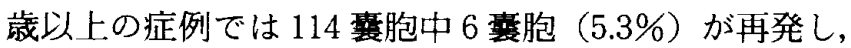
15 歳未満および 15 歳以上の症例との間に著差は認めな

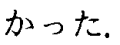

次に，治療法別に再発例をみると，開空術では， 10

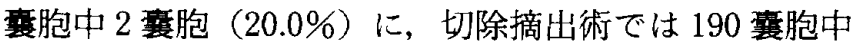
7 襄胞 (3.7\%) に再発がみられ，全般的には開空術が 切除摘出術に比へ，再発率が高くなっていた。しかしな がら，小児では，開空術が実施された症例が少ないもの の, 再発例はみられなかった（表 6 ）。

次に, 性別と再発率についてみると, 男では 82 襄胞 中 2 襄胞 (2.4\%) が，また女です 118 敕胞中 7 襄胞 (5.9\%) が再発しており, 再発率では女が男の約 2 倍 であった。また，15歳未満の小児では，男児には 30 襄 胞中再発はなく，女児では 56 輷胞中 3 囊胞 $(5.4 \%)$ が 再発していた。 15 歳以上では男では 52 襄胞中 2 貫胞 (3.8\%)，女では 62 較胞中 4 亳胞 $(6.5 \%)$ が再発して いた，以上のようにいずれの年齢首でも，女に再発しや すい傾向がうかがわれた（表 7 ）。

\section{考察}

粘液輷胞は口腔粘膜に存在する大, 小唾液腺の流出障

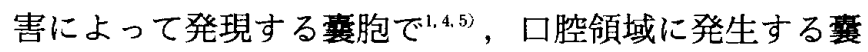
胞のなかでは，最も頻度の高い疾患である，石川ら $(1973)^{1)}$ は, 口底部に生じたガマ腫と, 前舌腺に関連 したブランダン腺囊胞をも含めて粘液囊胞とし，これま でに多くの報告がみられる

今回, 筆者らは, 15 歳未満を主とし, 対照として 15 歳以上の症例を調查し, 比較検討した。すすなわ，過去 13 年間に当科を受診し，加療を受けた，ガマ腫，ブラ ンダン腺亳胞を含む 195 症例の粘液襄胞を, 臨床的なら びに病理組織学的に，とくに 15 歳未満（日本小児口腔 外科学会対象年歯) の小児 84 例について調查し，15歳 以上の症例と比較検討した.

まず好発年齢についてみると，15 歳未満では 10 歳台 に最も多く，ついで 10 歳末満となり，15 歳未満の小児 例は調查全症例の $43.1 \%$ をし，小児に頻発していた。 なお，小児に好発する原因として Cataldo ら $(1970)^{10)}$ は歯の萌出による外傷を, Krolls ら (1972) ${ }^{11}$ ( は唾液腺 の分泌活動が盛んな時期とそれぞれ推測している.

性別発現頻度については，これまでの報告からすれば 女性に多いとされているが, 筆者らの集計調査であ, 男 女比は 1：1.4 と, 女性にわずかに多く, 黒豆ら（1983 
)$^{12)}$ 屯 $1: 1.6$, 左坚ら (1982 $)^{13)}$ は $1: 1.7$, 石田ら $(1980)^{14)}$ が $1: 1.4$ 上同様な男女比を報告しており， 筆者らの調查成績とほぼ類似していた。

一方，15歳未満の小児についてみると，自験 84 例に おける男女比は $1 ： 1.9$ と，女児での発現頻度が高く なっていた。ちなみ小澤ら（1987）吕は小児の粘液襄 胞 143 例を集計し，男女比は $1 ： 1.3$ であったと同様な 傾向を報告している．自験例では女児に多発していた が，その発生原因については明らかにしえなかった。し かし, 歯の萌出期, 成長ホルモンなどの関与が示唆され た.

部位別に発現頻度をみると，従来の報告では下唇に最 む多く発現しているが，自験例においても全症例の $56.9 \%$ が下唇に発現していた，以下，口底，舌下面など の順となり，石川ら $(1973)^{12}$, 石田ら $(1980)^{14)}$, 左 坐ら $(1982)^{13\rangle}$, 加藤ら $(1983)^{(5)}$, 横林ら $(1983)^{16)}$, 黒豆ら (1983) $)^{121}$ らが報告している， 口唇， 口底，舌の 順で, 類似する調査成績であった。

一方，15 歳未満の小児発現例についてみると, 自験 84 例のうち, 下唇が 52 例 (61.9\%) と最も多く, つい で，舌下面，口底の順であったが，舌下面での発現例は 小児に多く，15歳以上では口底発現例が多くなってい た。この点について，小澤ら $(1987)^{2)}$ の小児における 粘液囊胞の集計調查成績でも, 下唇が 92 例と最も多く 発現し，舌下面が 27 例でこれに続き，口腔底では，ガ マ腫と小唾液腺停滞囊胞をあわせて 22 例であり, 舌下 面発現例が多く，自験例と同様な傾向であった。

粘液囊胞の病理組織学的所見については, Cohen $(1965)^{17)}$, Harrison $(1975)^{18)}$ らが, 内面に上皮裏装 のみられない溢出型 (extravasion type) と, 上皮が 存在する停滞型（retention type）とに分類している. また，本邦においては，松岡ら $(1972)^{3)}$ が下唇粘液囊 胞 21 例を I 型 · 粘液肉芽腫型, II 型 · 異腫型, II 型 · 排 泄管拡張型の 3 型に分類し， その発生機序から孟型の上 うな，いわゆる眝留囊胞はまれ之報告している。この点 については Robinson (1964) $)^{19)}$ ， Lattanand (1970 )$^{20)}$, Cataldo ら $(1970)^{10)}$, 長谷川ら $(1977)^{21)}$ らむ 同様な見解を報告している。

筆者らは松岡ら $(1972)^{3)}$ の下唇粘液囊胞の分類に準 じて，自験 195 例を病理組織学的に検索し I 型， II 型， III型にそれぞれ分類を試みた，その結果， I 型・56 例 (28.7\%)， I型·136 例 $(69.8 \%) ，$ III型· 3 例 $(1.5 \%)$ となり, 諸家の報告と同様に I型が多く III型の頻度は著 しく低くなっていた。
次に 15 歳未満の小児例と, 15 歳以上の症例について 比較した。 15 歳未満の小监· 84 例では， I 型· 32 例 (38.1\%)， II 型· 51 例 $(60.7 \%) ，$ III型· 1 例 $(1.2 \%)$ であった。これに対し，15歳以上の 111 例では，I型・ 24 例 $(21.6 \%)$, II 型 $\cdot 85$ 例 $(76.6 \%), \quad$ III 型 $\cdot 2$ 例 (1.8\%) で， III型はいずれの年龄層ですすくなく， 15 歳以上では，II型が 85 例 $(76.6 \%)$ と多く， 15 歳末満 ではI 型が 38.1\% と多かった。 Bhaskar ら $(1956)^{22)}$ ， 松岡ら $(1972)^{33}$, 森ら (1977) ${ }^{23}$ 弓は, 粘液囊胞の発 現初期ではI型（粘液肉芽腫型）が多く，しだいに开型 （囊腫型）に移行するのではないかと推測している，筆 者らの集計成績でもこれに類する傾向がみられたが，明 確な根拠は得られなかった。

粘液襄胞の治療法としては, 異胞の大きさにもよる が, 従来加全摘出, 開空療法, 凍結療法, 薬物療法等 が報告されている る粘液襄胞については, 全摘出術が広く実施され, 経過 あ良好である ${ }^{24}$. また凍結療法むときとして報告されて いる ${ }^{25)}$. 粘液囊胞のうち口底に発現したガマ腫の場合, 全摘出術が最良の方法であることに異論はないが，襄胞 壁が菲薄であること, さらに襄胞が神経, 脈管, 顎下腺 管などに近接していることなどから ${ }^{26)}$, 開空術を施行す る場合が多い27 。しかしながら，不十分な開空術では再 発が多く, また, 開空に上る賈胞壁の污染·感染の危険 性が挙げられて28: シリコン系印象材を襄胞腔内に注入し て全摘出を試みる方法や ${ }^{29}$, 舌下腺の一部を含めた囊胞 摘出が報告されている30).

自験例 195 例のうち複数発現例が 4 例であり, そのう ち 2 霊胞の発現例が 3 例, 3 襄胞の発現例が 1 例で, 合 計 200 襄胞を対象として, 治療法についての集計調查を 行った。 また, 病理組織診断が明らかな症例にのみ限っ て調查し, 凍結手術を行った症例は除外した。

自験例 195 例 200 震胞中, 開空術が行われたのは $5.0 \%$ であった，治療法についてみると，横林ら（1983 )$^{16)}$ は粘液襄胞全体で摘出術が 65 例 $(66.3 \%)$, 開空術 は 33 例 $(33.7 \%)$ で, 左坐ら $(1982)^{13 \%}$ は, 摘出術を 188 例 (91.7\%)，開空術を 42 例（18.3\%）に施行した と報告している。これら諸家の報告に比へ，自験例では 切除摘出術が多く行われていた。

これを 15 歳未満の小児と, 15 歳以上で比較すると, 小児では 84 例· 86 剚胞中 2 例 $(2.3 \%)$ に開空術が行わ

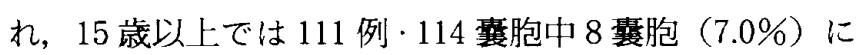
開空術が行われていた，小澤ら $(1987)^{2)}$ の小児粘液囊 胞の集計調查によると, 107 例のうち開空術は 13 例 
（12.1\%）に行われており，口底に発現したガマ腫に限 定すれば，18 例中 13 例と大多数に開空術が行われてい た。これに比較すれば自験例では小児例においても，切 除摘出術が多くなっていた。これは囊胞の大きさにもよ るが，再発の予防のため摘出手術を第一としたためであ る.

本疾患の予後について，囊胞の大・小にもよるが，石 田ら $(1980)^{14>}$ は 344 例中 17 例 (4.9\%), Cataldo ら $(1970)^{10)}$ は 594 例中 14 例 $(2.0 \%)$ ，小澤ら $(1987)^{2)}$ は小児粘液囊胞 143 例のうち 4 例 $(2.8 \%)$ であった之 報告している，自験例でも 195 例·200 襄胞のうち，再 発は 9 襄胞 (4.5\%) であり, 諸家の報告とおおむね類 似するあのであった．また， 15 歳未満の小㫛では 3 震 胞 (3.5\%) に， 15 歳以上では 6 囊胞 $(5.3 \%)$ に再発が みられたが，とくに発現年秢的な差違は認められなかっ た。

治療法別に検討すると, 全般的には開空術のほうが切 除摘出術よりあ再発率が高くなっていたが，15 歳未満 の小児では，再発した 3 例はすべて切除摘出術を行った あのであった，その原因として，囊胞壁が薄いため術中 に一部損傷したり，病的な腺組織の遺残などが考えられ た。開空術では例数がきわめて少ないが現在まで再発を 認めていない.

\section{結語}

筆者らは 1978 年から 1990 年までの 13 年間に, 九州 歯科大学第 2 口腔外科を受診し, 加療を受け, 病理組織 学的に粘液讋胞之確定診断された 195 例のうち，とくに 小児例（15 歳未満例）について臨木的な調查，ならび に病理組織学的な検索を行い，以下の成績を得た。

1 ）小児発現例は 84 例であり，全体の $43.1 \%$ であっ た.

2) 性別発現頻度では, 自験例全般では男女比が 1 : 1.4 であったが，小児では $1 ： 1.9$ で，10 歳末満で 1 ： 2.6, 15 歳未満で $1: 1.3$ となり, 女児に多発する傾向で あった。

3 ）部位別発現頻度では，小児では，下唇，舌下面， 口底の順で, 15 歳以上では下唇, 口底, 煩粘膜の順で あった。

4 ) 病理組織学的には，松岡ら $(1972)^{3)}$ の分類に準 じ検索したが，全般的には I 型·56 例 (28.7\%)， II 型· 136 例（69.8\%)，正型· 3 例（1.5\%）であった。

小児では， I 型 · 32 例 $(38.1 \%) ， \quad I$ 型 · 51 例 $(60.7 \%), \quad$ III 型· 1 例 $(1.2 \%)$ で, 15 歳以上例では I
型· 24 例 $(21.6 \%), \quad$ II 型 $\cdot 85$ 例 $(76.6 \%), \quad$ III型 $\cdot 2$ 例 (11.8\%) であった.

$5 ）$ 治療法では, 小児の 84 例 $\cdot 86$ 霊胞中, 開空術が 行われたのは 2 震胞で, 大多数の症例で 15 歳以上の症 例已同様に切除摘出術が行われていた.

6）予後については, 小児 84 例 86 異胞のうち 3 例 (3.5\%) が再発し，15 歳以上では 6 例 $(5.3 \%)$ に再発 がみられた。

本論文の要旨は, 第 3 回日本小児口腔外科学会（平成 3 年 12 月, 東京都) で発表した。

\section{引用文献}

1) 石川梧朗, 秋吉正豊: 口腔病理学 II. 永末書店, 京都, 1982, $429-433$.

2) 小澤孝紀, 水野明夫, 中村寿秀, 川端泰三, 茂野徹, 神 谷 浩, 柴田隆夫, 鈴木章司, 式守道夫, 茂木克俊: 小况 唾液腺停滞襄胞の検討。口科誌 $36: 138-144,1987$.

3）松岡泓美, 中村綃代：下口唇粘液囊腫. 皮の臨 $14: 224$ $-233,1972$.

4) Sela, J. and Ulmansky, M. : Mucous retention cyst of salivary glands. Oral Surg. 27:619-623, 1969.

5）清水正嗣：口腔領域軟組織の翼胞。蒾界㕕報 38: 1-9, 1976.

6) 山本康一：粘液襄胞. 歯科ジャーナル $13: 13-22$, 1981.

7 ）矢野茂良，暒山 稔，黒川英雄. 銅城将紘，飯野悦朗，中 村憲司：口腔領域における粘液螤胞の臨床的観察. 九州歯 会誌 $36: 566-574,1982$.

8 ) 藤本和久, 山田博基, 玉城廣保: 当科比ける最近 11 年 問の唾液腺粘液豊胞に関する臨床統計的検討。日口外誌 $36: 2258-2265,1990$.

9 ) 山隈正人, 矢野茂良, 田中照真, 梶山 稔, 福山 宏:下 口唇正中部に発現した Mucocele の 1 例. 九州霜会誌 $34: 550-554,1981$.

10) Cataldo, E. and Mosadoni, A. : Mucoceles of the oral mucous membrane. Arch. Otolaryngol. $91: 360-365$, 1970.

11) Krolls, S. O., Trodahl, J. N. and Boyers, R. C. : Salivary gland lesion in children. A Surgery of 430 cases. Cancer $30: 459-469,1972$.

12）黑豆照雄: 口腔粘液表胞の臨床病理学的研究。日口外誌 $29: 393-403,1983$.

13）左垒春喜, 篠原正徳, 友寄喜樹, 田代英雄, 岡 增一郎：

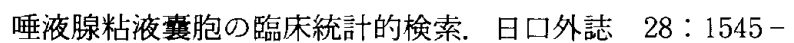
$1550,1982$.

14）石田 恵：口腔粘液麯胞の臨木的ならびに組織学的研究. 口病誌 $47: 447-464.1980$.

15）加藤卓雄, 林 升, 上田珠湖, 園田成美, 本田武司, 古本 克磨：唾液腺眝留襄胞の臨床統計的観察. 福岡歯会誌 $10: 209-213,1983$. 
16）横林敏夫, 横林康男, 上田 健, 中島民雄：口腔粘液赛胞 の臨床統計的検討，新潟歯会誌 $13: 23-27,1983$.

17) Cohen, L. : Mucocele of oral cavity. Oral Surg. 19 : $365-372,1965$.

18) Harrison, J. D. : Salivary mucoceles. Oral Surg. 39 : $268-278,1975$.

19) Robinson, L. and Hansen, E.: Pathologic changes associated with mucous retention cyst of minor salivary glands. Oral Surg. 18: $191-205,1964$.

20) Lattanand, A., Johnson, W. C. and Graham, J. H. : Mucous cyst (Mucocele). A clinicopathologic and histochemical study. Arch. Dermatol. 101:673-678, 1970.

21）長谷川 清, 井口 媇, 小川裕三, 吉岡千尋：口腔粘液瘤 100 例の統計的観察. 阪大歯誌 $22: 282-287,1977$.

22) Bhasker, S. N., Bolden, T. E. and Weinmann, M. D. : Pathogenesis of Mucoceles. J. Dent. Res. $35: 863-874$, 1956.

23）森 喜郎, 佐藤一郎, 村田睦男：臨床的に粘液腫を疑った 興味ある下口唇粘液衰胞の 1 例. 日口外誌 $23: 995$,
1977.

24）暒山稔，銅城将紘，寺坂修司：小唾液腺疾患および唾石 症の治療. 畨界展望 $53: 653-659,1979$.

25）平出文久, 井上鉄三，澤田政道，椿康喜代，都川紀正，田 中英一：凍結手術による下口唇および舌尖粘液較胞の治療 経験。耳喉 $54: 65-69,1982$.

26）内田 稔：ガマ腫. 小児内科 $11: 421-423 ， 1979$.

27）上田 健, 中島民雄, 常葉信雄：靧下型ガマ腫の 2 症例, 日口外誌 $25: 1208-1213,1979$.

28) Catone, G. A., Merrill, R. G. and Henny, F. A. : Sublingual gland mucous-escape phenomenon-treatment by excision of sublingual glands. Oral. Surg. $27: 241-242,1075$.

29）樋口俊夫, 泉 広次, 追川哲雄, 中川圭介, 吉田 亨, 増 田 剛, 岩崎 修, 築原昭道: シリコン注入による Ranula の摘出法. 口科誌 $24: 241-242,1975$.

30）篠原正徳, 左售春喜, 友寄喜樹, 田代英雄, 香月 武, 岡 増一郎：䫟下型ガマ腫 (Plunging ranula) の臨床的, 組 織学的検索. 日口外誌 $30: 222-230,1984$. 